\title{
"RHEUMATIC" IRITIS AND IRIDOCYCLITIS
}

\author{
BY
}

\author{
F. LENOCH, V. KRÁLÍK, AND J. BARTOŠ \\ From the Research Institute of Rheumatic Diseases \\ (Director: Prof. F. Lenoch, M.D.) \\ and the \\ First Ophthalmological Clinic \\ (Director: Prof. E. Diensthier, M.D.) \\ Prague
}

Every text-book of ophthalmology mentions "rheumatic" iritis and iridocyclitis, either as the sole manifestation of the rheumatic state or as one of a series of rheumatic symptoms. It appears, however, that this type of eye lesion is not associated with rheumatic conditions in general, but only with the clearly defined complaint known as ankylosing spondylitis.

We have studied some thousands of patients with rheumatic fever and have very rarely seen any ocular complications or iritis or iridocyclitis in particular. In no case has iritis been observed in an acute attack of rheumatic fever. It may be that our mode of treating rheumatic fever is so intensive and effective that eye complications do not develop, but we also have numerous patients who have undergone less thorough treatment elsewhere, and these cases also have been quite free from lesions of the iris. If rheumatic fever and iritis do appear together, therefore, their coincidence must be regarded as occurring by chance.

We have also had under our care tens of thousands of patients suffering from rheumatoid arthritis, and many of them have been under observation for many years, but lesions of the iris have been so rare that they cannot be regarded as complications of the arthritic condition.

The same may be said about degenerative joint disease, whether it affects the joints of the extremities (osteo-arthrosis) or of the vertebral column (spondylosis or spondylarthrosis deformans). The appearance of an iris lesion is so unusual that it is obviously unrelated to the articular disease.

However, the problem presents itself in quite a different light when considered in connexion with ankylosing spondylitis. Some dozens of cases have sufficed to prove that these ocular complications accompany the spinal lesions too often to be due to chance. Even if iritis and iridocyclitis cannot be accepted as complications in the other rheumatic conditions listed above, there seems to be no doubt that they quite frequently belong to the clinical picture of ankylosing spondylitis.

\section{Previous Investigations}

Graber-Duvernay (1944) found iritis or iridocyclitis in eleven of 33 patients with ankylosing spondylitis (33 per cent.). Schley (1937), who examined the lumbar spine of 73 patients suffering from "rheumatic iritis", was able to detect ankylosing spondylitis in 12.5 per cent. of them. We have the impression that this author did not devote enough attention to a careful study of the sacroiliac joint, the changes of which are usually specific, especially in the diagnosis of early cases. Had this joint been examined more closely, the number of positive cases would probably have been greater.

Ravault and Berthier (1944) discovered eight cases of iritis or iridocyclitis in 28 cases of ankylosing spondylitis (35 per cent.).

Michaud and Forestier (1954) saw uveal lesions only in seventeen of 200 patients with ankylosing spondylitis $(8 \cdot 5$ per cent.), but they point out that this must be considered as a very low figure because many of their cases were relatively recent ones.

Françon (1946) estimated the frequency of uveal manifestations at 60 per cent., but without giving precise statistical data.

Iritis and iridocyclitis were seen in 25 of 184 cases (13.5 per cent.) reported by Hart and Maclagan (1955).

\section{Present Series of Cases}

In our clinic we have seen over a thousand cases of ankylosing spondylitis in the last 20 or 30 years, and we have followed the majority of them for long periods.*

It was decided to ascertain what proportion of them had suffered from iritis and iridocyclitis, since

\footnotetext{
* These patients have founded a sports club called by them the O'Connor-Pierre Marie-Bechterew Sports Club, which unites them not only in sport, but also in social activities as a sort of a family of rheumatics all afficted with the same handicap. We have made an rheumatics all afficted with the same handicap. We have made an instructive film showing the sporting activities of this unusual club. Rheumatism, skilfully composed by Serge Larsen, the son of the much regretted French rheumatologist, Mathieu-Pierre Weil, was sung by the choir of this club and broadcast by the Bratislava broadcasting corporation in 1953 . It was without doubt the first occasion on which this March was broadcast.
} 
statistics had not previously been compiled for such a large series.

For various reasons it was impossible for us to re-examine all our patients and we were obliged to satisfy ourselves with checking 625 cases (570 males and 55 females).

Undoubted uveal affections were seen in 179 (28.9 per cent.), which included 163 men and sixteen women. These cases are distributed by age and sex in Table I.

As our standard was rather too strict than too liberal, this percentage does not by any means represent a maximum. In spite of the thoroughness with which we tried to discover all cases of iritis and iridocyclitis, we omitted those in which the diagnosis was at all doubtful.

In the second part of our study we examined a series of cases of iritis and iridocyclitis, the aetiology of which was obscure to the ophthalmologists, to find out whether unrecognized incipient ankylosing spondylosis was associated with the eye lesions. We assumed that such cases had developed subclinically or that the symptoms of spinal involvement had been so slight that the patient had paid no attention to them. If severe pain had occurred intermittently it was possible that neither the patient nor his doctor had suspected that the ocular lesions had any connexion with sporadic attacks of "lumbago" or "sciatica".

By arrangement with the First Clinic of Ophthalmology, all cases of iritis and iridocyclitis which fitted this description were referred to us, and we examined 474 patients with uveal lesions ( 269 males and 205 females), who are distributed by age groups in Table II (opposite).

Among these 474 patients with iritis and irido- cyclitis we found 91 with ankylosing spondylitis ( 17.4 per cent.), comprising 83 males $(30.8$ per cent.के and eight females (3.9 per cent.). In men the disease was found in all age groups from 20 to $9 \mathscr{Q}$ years, but in women only in the middle age group from 30 to 60 years. With only one exception the age distribution was exactly the same as in the series of ankylosing spondylitis patients with iritis.

Treatment.-One of our cases of ankylosing spondylitis? seems to deserve special mention. A teacher at a tech $\overrightarrow{0}$ nical college, aged 51, had suffered for many years with repeated attacks of iritis and iridocyclitis, each lasting a $\vec{\omega}$ least one month and some as long as 3 months. As he has regularly two attacks annually he was very often unabl to work for 6 months of the year. In 1950, however:we prescribed cortisone ointment for local ophthalmieo use just at the onset of a new attack of iritis. The effect was spectacular; all ocular signs disappeared withior 48 hours, although the patient could not remember anf previous occasion when the inflammation of the iris had subsided in less than 30 days. He was advised to appls the ointment, in the future, immediately he felt the firs symptoms of ocular involvement, and has since suc ceeded in keeping every threatened attack at bay, and has. not lost a day's work in 6 years.

\section{Summary}

(1) Iritis and iridocyclitis do not appear mor frequently in patients suffering from rheumatio fever or rheumatoid arthritis than in patients wit| other diseases or in persons in good health.

(2) Patients with degenerative joint disease of the extremities or of the spine manifest iritis and irido cyclitis only with extreme rarity.

(3) Iritis and iridocyclitis frequently accompan ankylosing spondylitis. Different authors havẹ

TABLE I

CASES OF ANKYLOSING SPONDYLITIS IN WHICH IRITIS WAS ALSO PRESENT, BY AGE AND SEX

\begin{tabular}{|c|c|c|c|c|c|c|c|c|c|}
\hline \multirow{2}{*}{$\begin{array}{l}\text { Age Group } \\
\text { (yrs) }\end{array}$} & \multicolumn{3}{|c|}{ Males } & \multicolumn{3}{|c|}{ Females } & \multicolumn{3}{|c|}{ Total } \\
\hline & Iritis & $\begin{array}{l}\text { Without } \\
\text { Iritis }\end{array}$ & Total & Iritis & $\begin{array}{l}\text { Without } \\
\text { Iritis }\end{array}$ & Total & Iritis & $\begin{array}{l}\text { Without } \\
\text { Iritis }\end{array}$ & Total \\
\hline $11-20$ & 0 & 5 & 5 & 1 & 1 & 2 & 1 & 6 & 7 \\
\hline $21-30$ & 8 & 35 & 43 & 0 & 5 & 5 & 8 & 40 & 48 \\
\hline $31-40$ & 25 & 90 & 115 & 3 & 12 & 15 & 28 & 102 & 130 \\
\hline $41-50$ & 55 & 132 & 187 & 6 & 15 & 21 & 61 & 147 & 208 \\
\hline $51-60$ & 49 & 111 & 160 & 4 & 3 & 7 & 53 & 114 & 167 \\
\hline $61-70$ & 23 & 31 & 54 & 2 & 2 & 4 & 25 & 33 & 58 \\
\hline $71-80$ & 2 & 2 & 4 & 0 & 1 & 1 & 2 & 3 & 5 \\
\hline $81-90$ & 1 & 1 & 2 & 0 & 0 & 0 & 1 & 1 & 2 \\
\hline $\begin{array}{l}\text { Total No. } \\
\text { Per cent. }\end{array}$ & $\begin{array}{l}163 \\
28 \cdot 6\end{array}$ & $\begin{array}{l}407 \\
71 \cdot 4\end{array}$ & $\begin{array}{l}570 \\
100\end{array}$ & $\begin{array}{l}16 \\
29 \cdot 1\end{array}$ & 39.9 & $\begin{array}{r}55 \\
100\end{array}$ & $\begin{array}{r}179 \\
28 \cdot 9\end{array}$ & 446 & $\begin{array}{l}625 \\
100\end{array}$ \\
\hline
\end{tabular}


TABLE II

CASES OF IRITIS AND IRIDOCYCLITIS IN WHICH ANKYLOSING SPONDYLITIS WAS DETECTED, BY AGE AND SEX

\begin{tabular}{|c|c|c|c|c|c|c|c|c|c|}
\hline \multirow{2}{*}{$\begin{array}{c}\text { Age Group } \\
(y r s)\end{array}$} & \multicolumn{3}{|c|}{ Males } & \multicolumn{3}{|c|}{ Females } & \multicolumn{3}{|c|}{ Total } \\
\hline & $\begin{array}{l}\text { Spine } \\
\text { Negative }\end{array}$ & $\begin{array}{l}\text { Ankylosing } \\
\text { Spondylitis }\end{array}$ & Total & $\begin{array}{l}\text { Spine } \\
\text { Negative }\end{array}$ & $\begin{array}{l}\text { Ankylosing } \\
\text { Spondylitis }\end{array}$ & Total & $\begin{array}{l}\text { Spine } \\
\text { Negative }\end{array}$ & $\begin{array}{l}\text { Ankylosing } \\
\text { Spondylitis }\end{array}$ & Total \\
\hline $11-20$ & 2 & 0 & 2 & 4 & 0 & 4 & 6 & & 6 \\
\hline $21-30$ & $12^{\circ}$ & 6 & 18 & 23 & 0 & 23 & 35 & 6 & 41 \\
\hline $31-40$ & 28 & 10 & 38 & 17 & 1 & 18 & 45 & 11 & 56 \\
\hline $41-50$ & 52 & 25 & 77 & 48 & 5 & 53 & 100 & 30 & 130 \\
\hline $51-60$ & 56 & 23 & 79 & 57 & 2 & 59 & 113 & 25 & 138 \\
\hline $61-70$ & 23 & 16 & 39 & 35 & 0 & 35 & 58 & 16 & 74 \\
\hline $71-80$ & 12 & 2 & 14 & 12 & 0 & 12 & 24 & 2 & 26 \\
\hline $81-90$ & 1 & 1 & 2 & 1 & 0 & 1 & 2 & 1 & 3 \\
\hline $\begin{array}{l}\text { Total No. } \\
\text { Per cent. }\end{array}$ & $\begin{array}{c}186 \\
69 \cdot 1\end{array}$ & $\begin{array}{l}83 \\
30 \cdot 9\end{array}$ & $\begin{array}{l}269 \\
100\end{array}$ & $\begin{array}{l}197 \\
96 \cdot 1\end{array}$ & $\begin{array}{l}8 \\
3 \cdot 9\end{array}$ & $\begin{array}{l}205 \\
100\end{array}$ & $\begin{array}{l}383 \\
80 \cdot 8\end{array}$ & $\begin{array}{l}91 \\
19 \cdot 2\end{array}$ & $\begin{array}{l}474 \\
100\end{array}$ \\
\hline
\end{tabular}

estimated the frequency of these ocular complications at from 10 to 60 per cent., but their findings have not been checked against a sufficiently large series of cases.

(4) The authors have carefully re-examined 625 subjects with ankylosing spondylitis and have ascertained that $179(28.9$ per cent.) had undoubtedly suffered from uveal lesions. This included 163 of 570 males ( $28 \cdot 6$ per cent.) and 16 of 55 females $(29 \cdot 1$ per cent.).

(5) The authors have also examined 474 adult patients with iritis or iridocyclitis of unknown aetiology. Among 269 males 83 cases of unsuspected ankylosing spondylitis were found $(30 \cdot 8$ per cent.) and among 205 females only eight such cases (3.9 per cent.).

(6) The conclusion is drawn that every case of iritis and iridocyclitis of unknown origin should be examined for latent or incipient ankylosing spondylitis.

(7) When such attacks of iritis occur they can be treated with local cortisone ointment.

\section{REFERENCES}

Françon, F. (1946). "Conférences cliniques de rhumatologie pratique" (première série). Vigot, Paris.

Graber-Duvernay, J. (1944). Arch. Rhum., 5, 203.

Hart. F. Dudley, and Maclagan, N. F. (1955). Ann. rheum. Dis., $14,77$.

Michaud, P., and Forestier, J. (1954). Rev. Rhum., 21, 489.

Ravault, P., and Berthier, L. (1944). Lyon méd., 172, 119.

Schley, H. (1937). Klin. Mbl. Augenheilk., 98, 780.

\section{Irite et iridocyclite "rhumatismales"

$$
\text { RÉSUMÉ }
$$

(1) L'irite et l'iridocyclite ne surviennent pas plus souvent au cours du rhumatisme articulaire aigu ou de l'arthrite rhumatismale que chez des sujets sains ou atteints d'autres maladies.

(2) Les sujets atteints de maladies dégénératives articulaires des extrémités ou du rachis ne souffrent que très rarement d'irite ou d'iridocyclite.

(3) L'irite et l'iridocyclite accompagnent souvent la spondylarthrite ankylosante. De différents auteurs ont estimé la fréquence de ces complications oculaires à de 10 à 60 pour cent, mais leurs résultats n'ont pas été vérifiés par un nombre suffisant des cas.

(4) Les auteurs ont re-examiné soigneusement 625 sujets atteints de spondylarthrite ankylosante et trouvé que $179(28,9 \%)$ d'entre eux avait certainement eu des lésions uvéales. Ce nombre comprenait 163 sur 570 hommes $(28,6 \%)$ et 16 sur 55 femmes $(29,1 \%)$.

(5) Les auteurs ont aussi examiné 474 malades adultes atteints d'irite ou d'iridocyclite d'étiologie inconnue. Parmi 269 mâles on a trouvé 83 cas de spondylarthrite ankylosante insoupçonné, mais parmi 205 femelles on n'en a trouvé que huit.

(6) On en tire la conclusion que dans chaque cas d'irite ou d'iridocyclite d'origine inconnue on doit rechercher la spondylarthrite ankylosante, latente ou naissante.

(7) Chaque attaque d'une telle irite peut être traitéé par une pommade oculaire à la cortisone.

\section{Iritis e iridociclitis "reumáticas"}

\section{Sumario}

(1) La iritis y la iridociclitis no ocurren más a menudo en el curso del reumatismo poliarticular agudo o de la artritis reumatoide que en otras enfermedades o en sujetos sanos.

(2) Los sujetos con enfermedades degenerativas articulares de las extremidades o de la columna vertebral padecen muy raramente de iritis o de iridociclitis. 
(3) La iritis y la iridociclitis acompañan frecuentemente la espondilartritis anquilosante. Varios autores han estimado la frecuencia de estas complicaciones oculares a de 10 a 60 por ciento, pero estos datos no fueron averiguados por un número suficiente de casos.

(4) Los autores re-examinaron cuidadosamente 625 casos con espondilartritis anquilosante y encontraron que $179(28,9 \%)$ de estos habian indudablemente tenido lesiones uveales. Este nombre comprende 163 de 570 hombres $(28,6 \%)$ y 16 de 55 mujeres $(29,1 \%)$.
(5) Los autores investigaron también 474 enfermo adultos con iritis o iridociclitis de origen desconocida? Entre 269 hombres encontraron 83 casos de espondi artritis anquilosante no sospechados, pero sólo och entre 205 mujeres.

(6) Se concluye que en cada caso de iritis o de iridos ciclitis de origen desconocido, se debe buscar la espondis artritis anquilosante, latente o naciente.

(7) Ataques de iritis de este tipo pueden tratarse con aplicaciones locales de cortisona. 